\title{
ノロウイルスの流行と遺伝子型
}

\section{The Circulatory Dynamism of Norovirus and Impact to Immunity}

\author{
左近直美 $* 1, \dagger$ ・駒野 淳 $* 2$ \\ $(* 1$ 大阪府立公衆衛生研究所 感染症部ウイルス課, $* 2$ 名古屋医療センター統括診療部臨床検査科) \\ Naomi SAKON* and Jun Komano* \\ (*1 Department of Infectious Diseases Division of Virology, Osaka Prefectural Institute of Public Health, \\ 1-3-69 Nakamichi, Higashinari-ku, Osaka 537-0025; \\ *2 Department of Clinical Laboratory, Nagoya Medical Center, \\ 4-1-1 Sannomaru, Naka-ku, Nagoya 460-0001; \\ ${ }^{\dagger}$ Corresponding author)
}

\section{1. はじめに}

ノロウイルスは1972年にウイルス性下痢症の原因と して同定され ${ }^{33)}$, 世界的に流行している ${ }^{1,45)}$. 疫学情報 の積み重ねにより, ノロウイルスはヒトの全年齢層に感 染すること ${ }^{27)}$, 再感染を認めること ${ }^{60,61)}$, 接触感染, 飛沫感染, 空気感染という多様な感染ルートを持つこ と $^{34,35,50)}$, 食中毒 ${ }^{56)}$ の原因になることなどがわかって いる．遺伝子の変異によって生じた変異株が大規模な世 界的流行を引き起こしている ${ }^{21,36,44)}$ ，実用レベルでの 培養には成功しておらず, ウイルスの生化学的性状, 受 容体, 宿主免疫など未解明な点が多く残されており, そ れが効果的な感染対策のハードルとなっている.

ノロウイルスはCaliciviridae（カリシウイルス科）に 属する. カリシウイルス科にはNorovirus, Sapovirus, Vesivirus, Lagovirus, Nebovirus 属 ${ }^{2)}$ が含まれる. カリ シウイルス科には多岐にわたる宿主が報告されており, Norovirus属とSapovirus属がヒトに胃腸炎を引き起こ す. Norovirus属にはノーウォークウイルス種のみが属 しており，一般的に使用されているノロウイルスは分類 学のうえではノーウォークウイルスが正しい種名である.

ノロウイルスはGenogroup I〜V $(\mathrm{GI} \sim \mathrm{GV})$ に分類さ れる五つの遺伝子グループが存在し, GI, GII, GIVはヒ ト，GIIIはウシ，GVはマウスから検出される，GIは9 種類, GII は 22 種類, GIII は 2 種類の遺伝子型に分類さ れ, Genogroupの後ろにドットと数字で表記される ${ }^{37)}$. たとえば, GIIの遺伝子型 4 の場合 GII.4となる．2015年 以前は国内表記にスラッシュとドットが混在していた

\footnotetext{
†連絡先

*1 焉537-0025 大阪市東成区中通 1-3-69

*2 焉460-0001 名古屋市中区三の丸 4-1-1
}

が，現在はドットに統一された。一部では遺伝子型の番 号が不一致のものが存在するので, 注意が必要である. 例として, 近年流行している GII.17 はGII/11 と表記さ れ，逆にGII/17はAlphatron夕イプと言われるウイル スでGIVに分類されている．以下のサイトで遺伝子型 比較ができるので参照されたい. http://www.nih.go.jp/ niid/images/iasr/rapid/graph/Vol.36/graph/pt4274a. gif

ノロウイルスは1本のプラス鎖RNAをゲノムとし, その中に三つの ORFを持つ（図1)。ORF1にはRNAポ リメラーゼなどのウイルス複製に必要な各種酵素蛋白質 がコードされている，ORF2にはウイルス構造蛋白質 VP1が，ORF3には同じくVP2がコードされている．遺 伝子型が異なるウイルス株間での組換えウイルスは

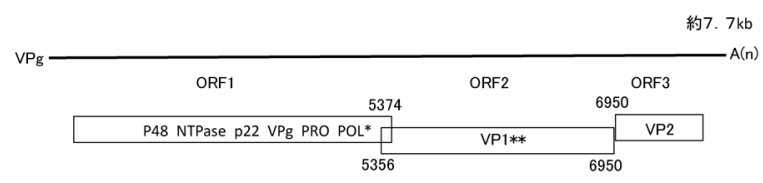

図1.ノロウイルスのゲノム構造図

ノロウイルス属は約 $7.7 \mathrm{~kb} の(+)$ 一本鎖 RNA を 遺伝子とする. 三つのオープンリーディングプレー ム $(\mathrm{ORF})$ を持ち，5'末端にはVPg を有している。 ORF1 は各種非構造蛋白質を, ORF2 と ORF3 は構 造蛋白質 VP1 とVP2 をコードする. ウイルス由来 のプロテアーゼ (Pro)によって ORF1の産物は六 つの蛋白質を作り出す. 同じ Genogroup に属する 異なる遺伝子型のウイルス株間で ORF1 と ORF2 の間で組み換えが起きる. POL*(RNA dependent RNA polymerase) と VP1**のゲノム領域それぞれ に遺伝子型分類がある。 p48 (NTPase), p22 (VPg), Pro (protease). nt は Norwalk virus $(\mathrm{Hu} / \mathrm{NoV} /$ Norwalk/1968/US, GeneBank Accession number M87661) に基づく. 
ORF1 と ORF2の間で起こることが多い ${ }^{48)}$.したがっ て, ウイルス株の遺伝子型はORF1のRNAポリメラー ゼ領域により実施される遺伝子型 $(\mathrm{P})$ と，VP1によって 決定される遺伝子型の両遺伝子型を表記し, GII.P17 GII.17のように表記する.

\section{2. ノロウイルス感染}

疫学：ノロウイルスは冬期を中心に流行し，毎年約 7 億人（世界人口の約 1 割）がノロウイルスによる急性ウ イルス性胃腸炎を罹患すると推定された ${ }^{8)}$ 。日本では正 確なノロウイルスによる急性胃腸炎患者数は把握されて いないが，食中毒における2011～2015年の全国統計から 推定される患者数は年平均 12,861 人である. ヒトーヒト 感染による集団発生の患者数は大阪府における同期間の 年平均患者報告数 7,807 人をもとにすると，日本では年 に11〜 12 万人と推計される. ノロウイルス感染患者はこ れらの合計に加え, 小児の散発性胃腸炎や有症苦情等も あるため毎年数十万人に上るのではないかと推定され る. 典型的な症状は嘔吐, 下痢, 吐き気, 腹痛, 発熱で, 数日で回復する。WHO゙定義する下痢症の基準（水様 便か通常よりも緩い便が1日 3 回以上）を満たさないノ ロウイルス感染者も多いと指摘されている ${ }^{35)}$ 。したがっ て，ノロウイルス感染者は統計以上に存在すると思われ る. 2006 2015年の厚生労働省の死因基本分類に基づく 統計では，腸管感染症による死亡者数は年間 2,000 人強 で，ウイルス性胃腸炎はそのうち $2 \sim 3 \%$ 占める。 そ の中でノロウイルスが死亡原因と報告される死亡者数は 年間数十名である（図2)。米国ではノロウイルスを原 因とする死亡者数は年間 $510 ８ 00$ 人と推計されており， 人口比から推定すると日本では 200～320人程度となる. 高齢者では誤嶼性肺炎などを引き起こし，間接的な死亡 の原因になる．感染伝播力が強く，高齢者福祉施設や保 育施設等での集団発生がしばしば報告される，遺伝子型

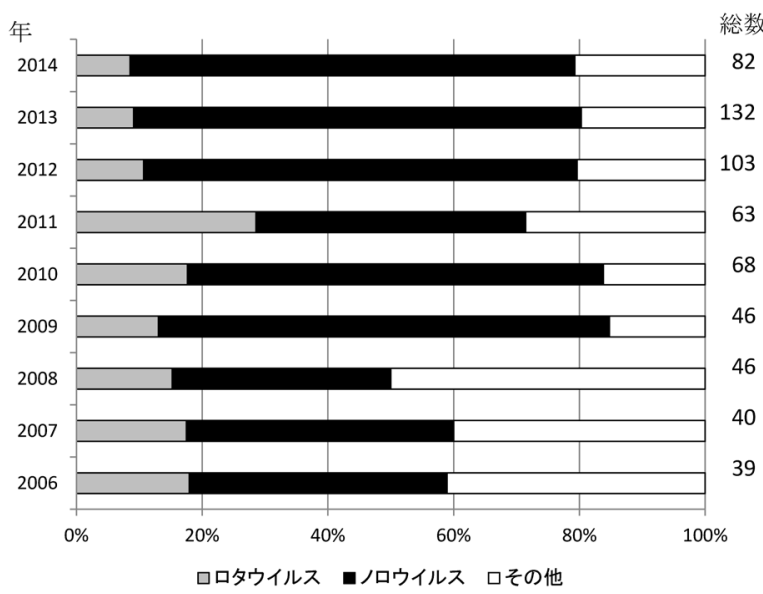

図 2. 死因基本分類に基づくウイルス性腸管感染症による 死亡に扮ける原因別割合 厚生労働省の疾病，傷害㧍よび死因統計分類年次別 死亡数データより作成.
別では, GII.4が最も検出頻度が高い（下記に詳述）.

病理：ボランティアによる臨床研究で得られた感染者 における小腸バイオプシーの病理解析では, ノロウイル ス感染により小腸微絨毛の扁平化が確認されている。し かし，バイオプシーで得た小腸上皮細胞中にウイルス粒 子は観察されなかった ${ }^{65)}$. 病原性の観点からは, GII.4 がほかの遺伝子型に比べて有症期間が長いと指摘されて いる ${ }^{60)}$

感染：10～1,000個のウイルス粒子で感染が成立す $3^{4,68)}$. 受容体は同定されていない。組織血液型抗原と ノロウイルス遺伝子型の間に結合親和性の関係が報告さ れている. 組織血液型抗原が分泌されない非分泌型の七 トではノロウイルスGI.1 は感染しない30,38)。しかし, 非分泌型のヒトにGI.1 以外のノロウイルスは感染する ${ }^{57)}$. 非分泌型に対して，分泌型の組織血液型抗原を持つヒト ではノロウイルス感染頻度は有意に高くなる ${ }^{18,40)}$ 。し たがって, 組織血液型抗原はノロウイルス受容体ではな く，ウイルス遺伝子型によって異なる感染感受性を与え る宿主因子であると考えられる。 ウイルスの排泄は 6 力 月齢までと高齢者および免疫不全や慢性疾患患者では長 期化する $15,25,49,67,73)$

不顕性感染：小児において繰返し感染しているが症 状を呈さない不顕性ノロウイルス感染が認められてい る $12,58,60)$. また, 成人においても不顕性感染は認めら れている $5,7,51)$ 。われわれの独自の調査においても, 繰 返しノロウイルス感染が検出された幼児において顕性, 不顕性感染のいずれも認められた。言い換えると，1個 体で両方の臨床像を呈する可能性を示唆する。獲得した 抗体によって症状が抑えられるとすれば，ウイルスの排 泄量（ウイルス複製）が抑制されていてよいはずである が，不顕性感染におけるウイルス排泄量が発症者と同程 度であることから，ウイルス増殖を許容しつつも発症を 防御する未知のメカニズムが存在すると考えられる ${ }^{64)}$.

免疫：ノロウイルス感染により遺伝子型特異的な防御 免疫が誘導される。ボランティアにおける臨床研究では, ノロウイルス感染で誘導された免疫は同一遺伝子型のウ イルスに対して約 6 力月間再感染を防御できることが示 された ${ }^{31)}$. 再感染時には, 過去に感染したノロウイルス 遺伝子型に対する特異的 $\operatorname{IgA}$ が速やかに誘導される ${ }^{54)}$. しかし, 異なる遺伝子型のノロウイルス感染は防御でき ない59)

われわれの疫学研究によると, 出生後 6 年間観察を持 続した小児では 8 回に上るノロウイルス感染エピソード を認めた。そのうち同一遺伝子型による再感染は 3 回認 められ，その間隔は23〜46力月であった。この結果は, 遺伝子型特異的免疫は約 2 年持続する可能性を示唆する. ヒト集団の疫学調査でも同様の結果を得ている ${ }^{61)}$. 再感 染で検出されたウイルス株は前に感染した株とVP1の 5 末端約 $300 n t に 4 \%$ の不一致を認めたことから，再感染 は抗原性の変異を伴っている可能性もある（Sakon投稿 
中)。したがって，免疫が持続する期間はより長いかも しれない。世界的流行を見せている GII.4も数年おきに 流行株は変遷し，そのVP1におけるB細胞エピトープ には変異が認められる。つまり，ノロウイルスに対する 獲得免疫は, 遺伝子型特異的ではなくウイルス株特異的 と認識すべきかもしれない64).

\section{3. ノロウイルスの流行と遺伝子型}

世界的な流行株：30 以上に上る遺伝子型が存在する なか, GII.4は過去 20 年以上にわたってノロウイルス流 行の主要な遺伝子型となっており, 変異株の出現に伴っ て世界的な大流行を引き起こしている ${ }^{1,14,22,61,62)}$. GII.4 変異株は $2 \sim 3$ 年おきに出現し, 集団免疫を回避するよ うにB細胞エピトープに変異を伴っている ${ }^{13,23,26,47)}$ 。 ま た, 変異が組織血液型抗原への親和性の変化を伴うこと も流行する要因の一つと思われる11).

長期間の系統的な流行調査：ノロウイルスに対する免 疫の持続および多様な遺伝子型に対する交差免疫性を明 らかにするため，われわれは長期間にわたる自然感染事 例の系統的調査を実施した。大阪府では三つの系統だっ た感染性胃腸炎調査が実施されている。一つは感染症発 生動向調査に基づき，府内 18 （平成 28 年度）の病原体 定点病院から散発性胃腸炎と診断された症例における病 原体検索, 二つめは「社会福祉施設等における感染症等
発生時に係る報告について」(平成 17 年 2 月 22 日健発第 0222002 号薬食発第0222001号 雇児発第0222001号 社 援発第0222002号 老発第0222001号）に基づき保健所に 届け出された社会福祉施設等における 10 人以上の患者 発生事例，三つめは食品衛生法に基づき保健所に届け出 された食中毒 (疑い) 事例である。上記の 3 系統から得 られた症例を年齢に基づき 4 グループに分類した。 グ ループAは年齢を 0 14歳の散発性胃腸炎症例，グルー プBは0〜14歳の集団発生事例，グループCは15〜64歳 の食中毒事例，グループ D は 65 歳以上で集団発生事例 である。各グループにおけるノロウイル遺伝子型を年度 別に解析すると，グループ A C C およびDでは GII.4が常 に主要な遺伝子型であった。 しかし，グループBでは流 行の主要な遺伝子型がシーズンによって異なることがわ かった（図3）。これは，幼少期の集団生活において多 様な遺伝子型のノロウイルスに暴露されることを意味す る. 保育所や小学校等では遺伝子型特異的に集団免疫が 存在し, その免疫は次のシーズンに同じ遺伝子型の流行 を阻止することができる，GII.4は小児集団において新 型の出現した2006/07 と2012/13 シーズンのみ主要な遺 伝子型となっていた。しかしながら, グループBの構成 年齢を細分化し同様の解析を実施すると，2歳までは集 団の流行遺伝子型ではなくGII.4が主要であることがわ かった．以上より，乳幼児期には両親からの感染機会が
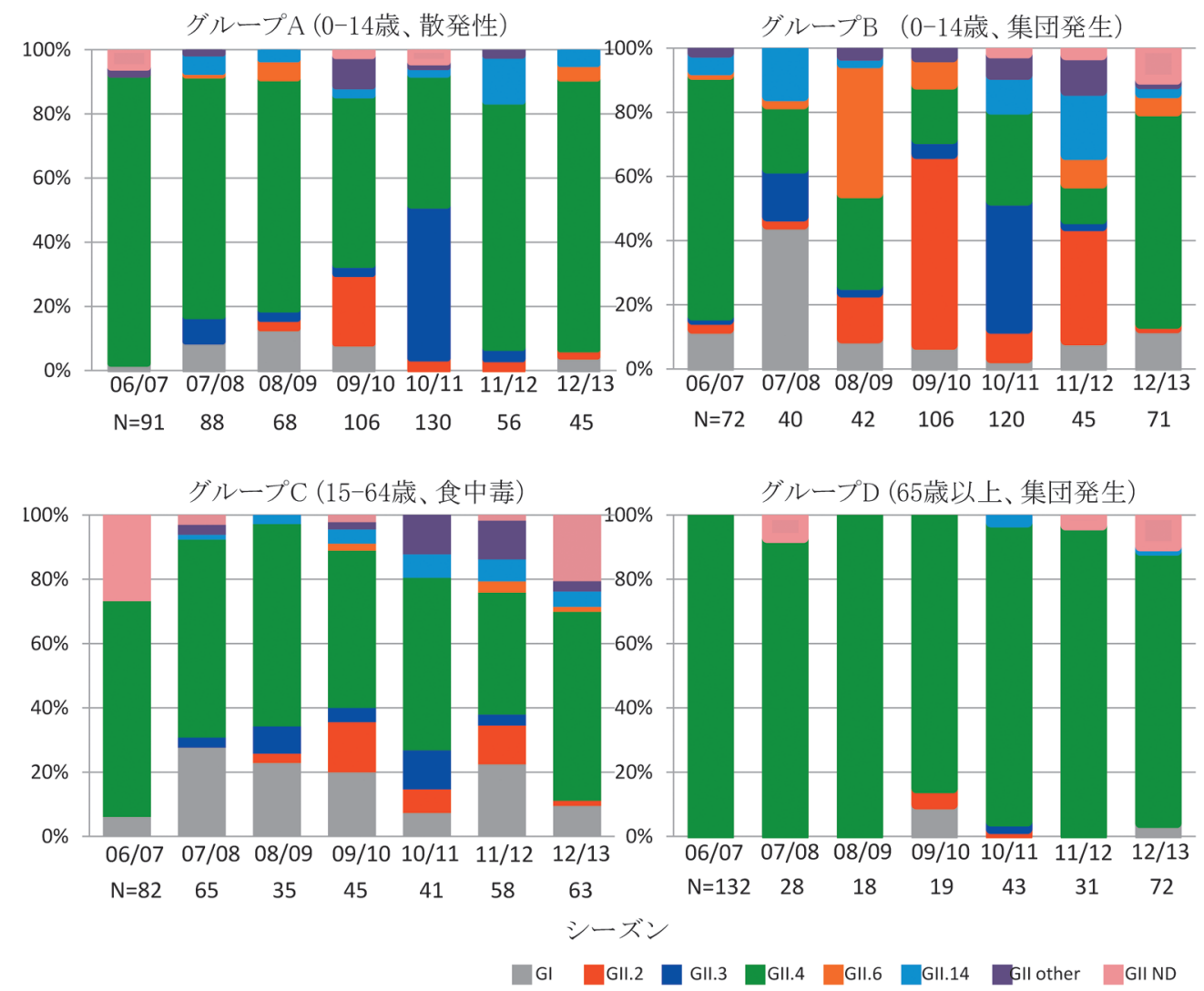

図3. 異なるヒト集団における流行シーズン別ノロウイルス遺伝子型検出頻度

2006/07(06/07) から 2012/13(12/13) までの各流行シーズンに検出されたノロウイルス遺伝子型の割合を四つの異なるヒ 卜集団 (グループ $\mathrm{A} \sim \mathrm{D}$, 本文参照) ごとに記す. 各グラフ下の数字 $(N)$ は症例数もしくは事例数. 
多く, 高齢者施設では外部からの持ち込みが主たる要因 であることから，グループ A とグループ Bの2歳未満, グループ D は成人層に広く流行している GII.4が主要な 遺伝子型となることが推察された。 人口構成比で成人層 は最も高く, GII.4未感染者が多いため, GII.4の流行が 遷延すると考えられる。そして，GII.4に対する集団免 疫を回避する新たな変異株が蔓延する ${ }^{19,20)}$ 。また，集団 発生時の経過表より有症期間を年齢別に解析すると，年 齢と有症期間に逆相関関係があることが示された。

以上より，ノロウイルスに対して遺伝子型特異的な集 団免疫が存在し，2３年は同一の遺伝子型によるノ口 ウイルス流行を抑止できること，幼少期に多様な遺伝子 型の暴露を受け, 獲得免疫が年齢とともに増強されるこ とで有症期間の短縮につながることが推察された ${ }^{61)}$. この知見は, 前述の小児例の追跡調査で得られた知見と よく一致する.これらの疫学データから ${ }^{19,61)}$, われわ れはノロウイルスの遺伝子型と免疫の関係をもとにノロ ウイルスの環境サイクルが図4のようであると理解して いる.

GII.17の出現：ノロウイルス遺伝子型GII.17（旧 GII/11）は報告のまれな型であったが，2014年12月〜 2015 年 3 月にかけて全国の食中毒事例から検出が相次い だ. 国への食中毒の届け出にはノロウイルス遺伝子型を 報告する必要はなく，また病原微生物検出情報に食中毒 事例を積極的に登録していないため，流行している遺伝 子型の正確な状況は把握できない。今般「食中毒対策の 推進について」(平成 28 年 4 月 1 日生食監発 0401 第 1 号) において塩基配列の決定を行い報告することが通知され たので, 分子疫学情報が充実すると期待される。遺伝学 的には, GII.17は二つのsub-clusterが流行しており，そ れぞれKawasaki308 と Kawasaki323が代表株である. 前者や中国山東省での流行株Guanzhou41621が属する 系統が世界的に検出されている ${ }^{42,46)}$ 。両系統は過去に

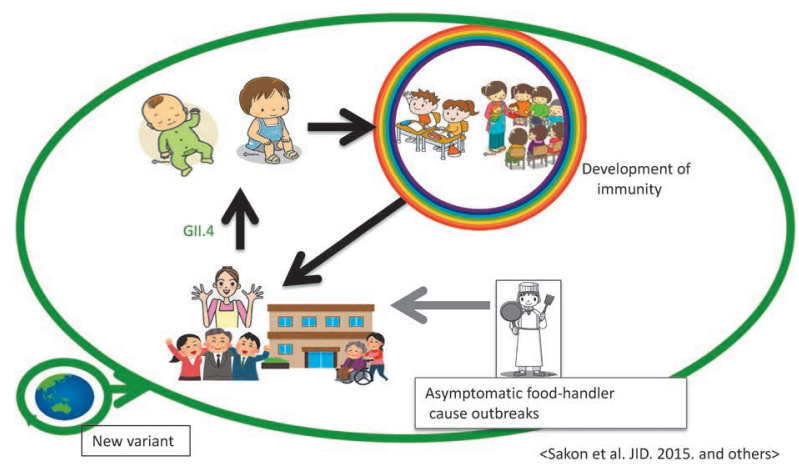

図4.ノロウイルスの循環と免疫の関係 ノロウイルスに対する免疫の獲得と流行する遺伝子 型の関係を示す，幼少期の集団生活において，多く の遺伝子型に繰返し暴露を受け一定の免疫力を獲得 すると考えられる。しかし，これらの免疫から回避 できる変異を獲得した GII.4 が成人を中心に世界的 な流行を繰返す。乳幼児は成人で流行するウイルス 株に影響を受けやすい.
検出されたウイルス株に比べてVP1のB cellエピトープ に多くの変異が認められる。 Kawasaki308系統は変異に 加え 2 塩基の挿入があり，これが流行した要因かもしれ ない。一方，感染症サーベイランスシステム NESID (National Epidemiological Surveillance of Infectious Disease)に収載されている国内散発性胃腸炎における病 原体検出情報によると，2014年10月から 2016年3月ま での間にノロウイルス 933 件が報告されており，そのう ち GII.17は56件 $(6 \%)$ であった。なお，大阪府における 2015 年度 GII.17検出状況は小览の散発性胃腸炎で $3.9 \%$ (2/51症例)，食中毒事例では $39.5 \%$ (15/38事例）で あった. GII.17が食中毒事例に高い割合を占める一方, 小児散発性胃腸炎での検出率が低い理由は不明である.

\section{4. 感染 経 路}

ノロウイルスの感染防御において，ウイルスの生活環 とヒトへの感染経路を理解し, 感染経路を遮断すること が必要である。しかしながら，ノロウイルスの感染経路 は多様で，高い環境抵抗性を持ち，少量のウイルスで発

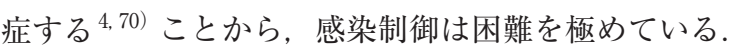

複製サイクル：培養系が確立していないため, 細胞レ ベルにおけるヒトノロウイルスの生活環はほとんど解明 されていない. 近年, 血液型抗原を産生する腸内細菌と 共感染させることで, マウスノロウイルスやヒトノロウ

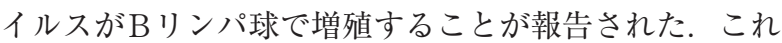
は感染に宿主の血液型抗原を必ずしも要しないこと，粘 膜バリアを突破して細胞内に侵入する必要があることを 示唆している ${ }^{32)}$ 。しかし，培養系としてはまだ改善の 余地がある．RNAを細胞導入すると限定的であるが複 製が認められることから，培養系が構築できない理由は ウイルスの吸着〜侵入過程に制限因子があるのかもしれ ない $16,55,69)$. 近縁のマウスノロウイルスの培養によっ てゲノムの翻訳および複製の分子機構の解明はある程度 解明された ${ }^{17,28,68,71)}$ ，細胞内で脱殼した後，ウイルス ゲノムの $5^{\prime}$ 末端の VPgが宿主細胞に翻訳開始因子とし て認識され翻訳が始まり, ウイルスのRNAポリメラー ゼによってゲノムが増幅される ${ }^{28)}$. 複製されたゲノム はVP1 とVP2からなるカプシドにパッケージされるが, その過程とそれに続くウイルス放出ステップはほとんど わかっていない.

ヒトへの感染経路：ノロウイルスはヒトに経口感染す る. 水系を污染するとカキをはじめとする二枚貝に取り 込まれる。これを生で摂食するとヒトに感染する。感染 の様式には污染二枚貝, 水あるいは二次的に污染された 食品の喫食によるもののほか，污染された環境に触れた 手指からの接触感染, 嘔吐物中のノロウイルスの暴露に よる飛沫感染がある，環境中で感染性が安定に保持され るため, 粉塵（空気）感染も起こしうる.

食中毒：2005年以降の食中毒統計によると，ノロウ イルスを原因とする食中毒患者数が最も多く，年間 1 万 


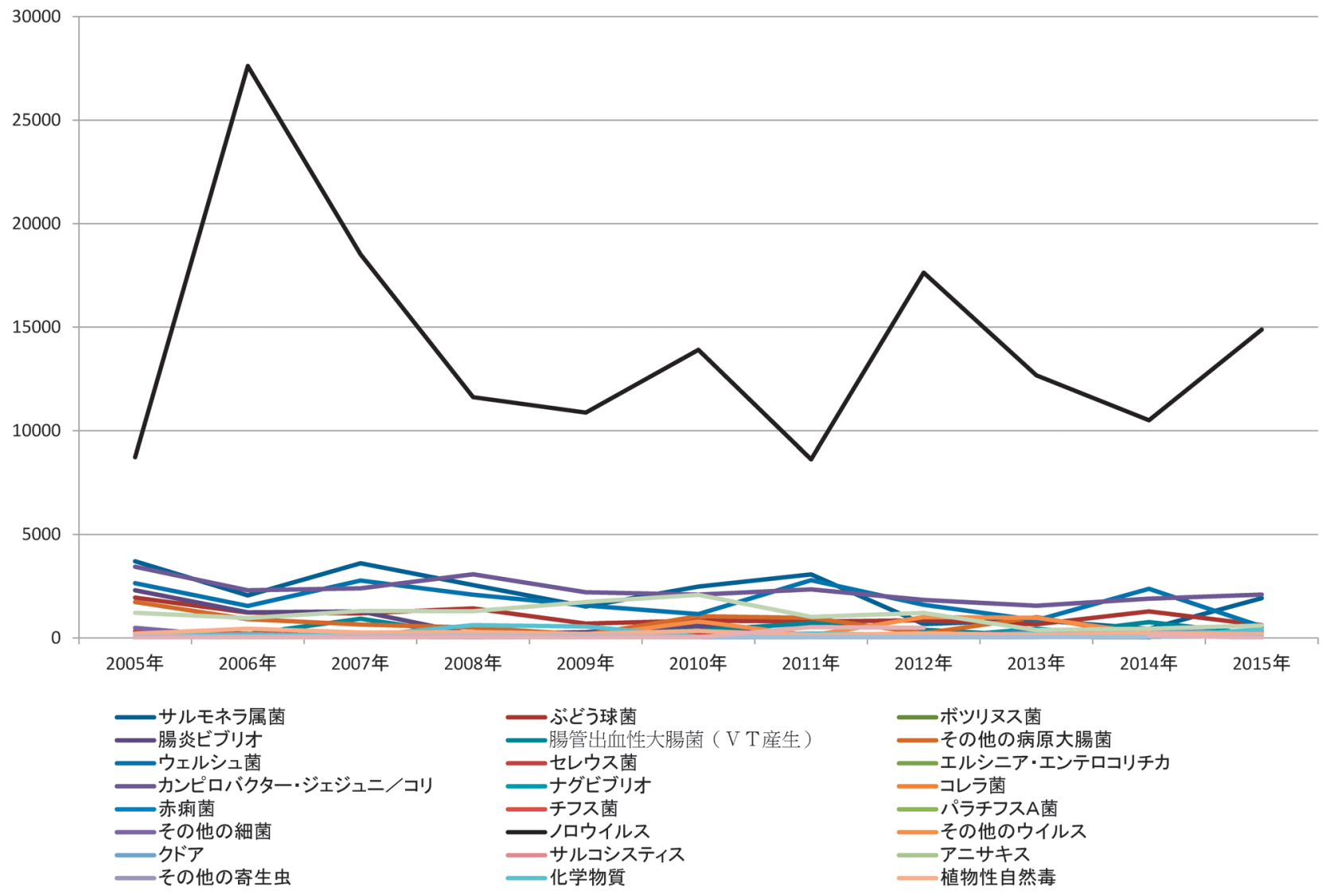

図 5. 2005 2015年の年別食中毒原因物質別の患者数

厚生労働省食中毒統計より集計.

表1．大規模食中毒事例一2003～2015年

\begin{tabular}{|c|c|c|c|c|c|c|}
\hline 発生年月 & $\begin{array}{c}\text { 発生場所 } \\
\text { 所在県 }\end{array}$ & 病因物質 & 喫食者数 & 患者数 & 原因施設 & 原因食品 \\
\hline $2012 / 12$ & 広島県 & ノロウイルス & 不明 & 2,035 & 仕出屋 & 不明（12/10,11, 12 に製造された弁当） \\
\hline $2006 / 12$ & 奈良県 & ノロウイルス & 4,137 & 1,734 & 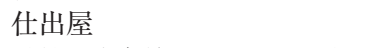 & 不明（仕出し弁当） \\
\hline $2011 / 2$ & 北海道 & サルモネラ属 & 2,758 & 1,522 & 学校-給食施設-共同調理場 & ブロッコリーサラダ \\
\hline $2012 / 12$ & 山梨県 & ノロウイルス & 3,775 & 1,442 & 仕出屋 ～～～～ & 12 月 11 日， 12 日に調理提供された弁当 \\
\hline 2014/1 & 静岡県 & ノロウイルス & 8,027 & 1,271 & 製造所 & 平成 26 年 1 月 13 日に製造された食パン \\
\hline $2015 / 12$ & 愛知県 & サルモネラ属 & 3,926 & 1,267 & 仕出屋 & 不明（12月7日の弁当） \\
\hline $2010 / 1$ & 岡山県 & ノロウイルス & 3,092 & 1,197 & 仕出屋 & 不明 \\
\hline $2007 / 9$ & 静岡県 & サルモネラ属 & 9,844 & 1,148 & 仕出屋 & 不明（仕出し弁当） \\
\hline $2011 / 12$ & 大阪府 & ウェルシュ菌 & 2,569 & 1,037 & その他 & 原因施設が調整した給食 \\
\hline $2007 / 1$ & 鳥取県 & ノロウイルス & 5,421 & 864 & 学校-給食施設-共同調理場 & かみかみ和え（推定） \\
\hline
\end{tabular}

厚生労働省食中毒統計より集計.

人前後である（図5). 患者数が増加している年は GII.4 の新型が出現した年であるが，2015年の増加は GII.17 の 出現が要因かもしれない.2003〜2015年の間で全国か ら報告された食中毒の患者数が多い10事例（2003〜 2015年）のうち，ノロウイルスを原因とするものは 6 事 例を占める（表1）。学校給食でノロウイルスが原因と なる食中毒の発生は2010年を除くすべての年で報告さ れている(図6).

水を原因とするアウトブレイクの発生も国内外問わず 発生している. 2016年に起こったスペインのミネラル
ウォーターを原因とする集団食中毒では 4,000 人以上が 発症した。このほか, 海外では冷凍イチゴやレタスなど の非加熱用食材が原因となった大規模な食中毒が発生し ている ${ }^{9,29)}$ (http://www.cspinet.org/foodsafety/IAFPPoster.pdf).

食品衛生管理：食品提供の場では食品の一次污染，調 理従事者による二次污染が想定される. ノロウイルスに 污染された二枚貝 ${ }^{41}$, 43) による食中毒はよく知られてい るが，ノロウイルスに感染した調理人による二次污染事 例は事例数, 患者数ともに多い ${ }^{24)}$. 特に不顕性感染者 


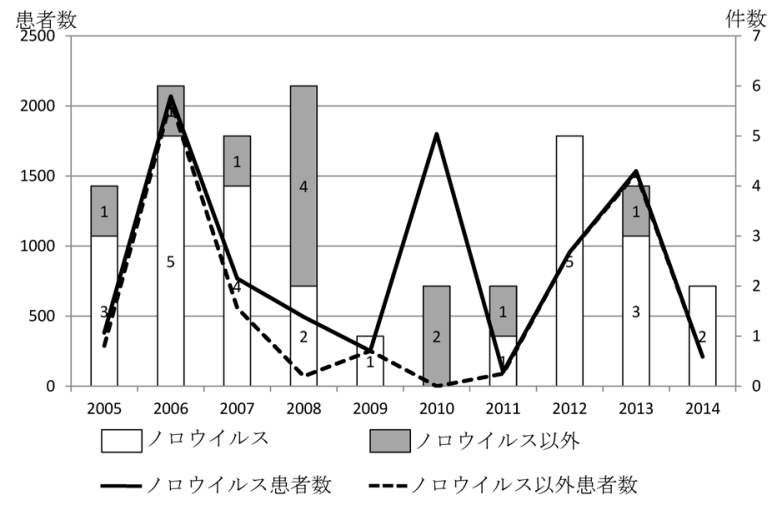

図6. 学校給食の年別食中毒事例におけるノロウイルスの 事例数と患者数（日本スポーツ振興センターまとめ より作成）

からの食品污染は問題である ${ }^{7,52)}$.

ノロウイルス胃腸炎が発生した場合, 環境の污染が次 の発生原因となりうる ${ }^{53)}$ 。 ノロウイルス陽性者が利用 したトイレを起点とするものや嘔吐物による環境污染で ある.ノロウイルスは環境中で物理的に比較的安定で, 長期間感染力を維持する. 地下水へのノロウイルス添加 実験では，少なくとも61日間は感染性が維持されてい た.さらに, RNase（RNAを分解する酵素）添加に よって粒子中のRNAを検出する方法では, 3 年以上 経ってもウイルスが検出されており，ノロウイルス粒子 の水環境における安定性が示されている66)

嘔吐：嘔吐物が感染拡大の原因となることはよく知ら れている. ボランティアでの四つの臨床研究で得られた 嘔吐に関する検証データが報告された ${ }^{35)}$ 。嘔吐はノロ ウイルス感染者の 40～100\%で認められ，下痢症状の有 無で胃腸炎症状を定義するとノロウイルス感染を見逃す 危険性がある。嘔吐物中のウイルスは平均 $1.7 \times 10 \mathrm{E} 8$ genomic equivalent copies (GEC)あり，重大な環境污 染源となる。しかし，反復する嘔吐における嘔吐物中の ノロウイルス量について詳細に検討したデータはない.

集団施設にて嘔吐があった場合, 周囲の人への暴露リ スクを低減させる意味で, 素早くその場から離れるよう 指示することが肝要である。周囲にいた人は必ず暴露さ れていると考え，2日以内に施設利用者および従業員の 発症を想定し，対応を考えておくことが必要である．嘔 吐物の処理が不適切であった場合は数日にかけて患者が 発生する。

\section{5. 社会的インパクトと対策}

ノロウイルス感染症による世界的な社会経済的損害が 初めて試算された ${ }^{8)}$ 。 ノロウイルス胃腸炎に毎年 7 億人 が罹患し， 22 万人が死亡していると推定され，ノロウ イルス感染症の対策に要する医療費は年間 42 億ドル （約 4,250億円）と試算された。さらに，罹患のための欠 勤や看護，生産性の低下などの社会的な損失は603億ド ル（約 6.1 兆円）と試算されている。一人あたりにかか
る医療費は 600 円程度であるが，社会経済的損失額は 9,000円程度となる。これまでワクチン施策は死亡率あ るいは重症度の高い疾病に対して優先的に講じられてき たが，この数字が示されたことにより，社会経済的リス クを軽減するためにノロウイルスワクチンの創製が重要 なミッションだという認識が共有された。

ワクチン開発における課題：現在開発中のワクチンは ウイルス様中空粒子(Viral-like protein; VLP)を抗原と して免疫を付与するもので, 臨床治験が行われている ワクチンはGI.1 と GII.4の 2 価ワクチンを筋肉内接種す $3^{3,6,10,72)}$. ウイルス様中空粒子は培養ができないノロ ウイルスでもワクチン抗原として大量に調整することが 可能である。しかし，ワクチンには課題も存在する。一 つ目は評価系である。ノロウイルスは培養できないう え，ヒトにおけるノロウイルス感染を再現する動物モデ ルも構築されていないため, ワクチンが賦与する免疫を 生物学的に評価することができない. ヒトでの臨床治験 に進んだ場合には，ワクチン効果を判定するために長期 間のコホート研究が必要となるため, 開発期間が著しく 長くなる恐れがある。 二つ目は遺伝子型である。過去の 流行から GII.4対策が優先され，抗原にGII.4が選択され てきた。一方，ノロウイルスに対する免疫は遺伝子型特 異的あるいはウイルス株特異的と考えられている，ノロ ウイルスには多くの遺伝子型が存在し，実際にGII.17の 流行が顕在化した今，多様な遺伝子型に対応することが 望まれる. 三つ目はワクチン誘導免疫の持続力である. 自然感染で誘導されるノロウイルスに対する免疫は, 長 くても数年程度しか持続しない. ワクチンで十分に長い 間，防御免疫を持続させることができるかは未知数であ る. 四つ目は変異である。 ノロウイルスは変異しやす い. 世界的なノロウイルス流行を引き起こしたウイルス は，過去に流行したウイルスに対する集団免疫から逃れ る変異を獲得している。したがって，ワクチンで誘導さ れた免疫に対しても容易に抵抗性のウイルス株が出現し てワクチンが無力化されるリスクがある.

高齢者施設等における対応：施設においては 10 月か ら 3 月のノロウイルス流行期は, トイレの清掃に次亜塩 素酸ナトリウムを使用し, 清掃回数を増やすことが望ま しい，手すり，ベッド柵，照明のスイッチなど手の接触 が多い場所についても次亜塩素酸ナトリウムによる拭き 掃除と水拭きが望ましい ${ }^{39)}$. 仕切りカーテンは手がよ く触れる場所であるが，清拭による消毒を実施しにくい ため，洗濯を行う。冬期は洗濯の実施日を決めておくの がよい。

施設内で発症者を認めた場合は，発症者のトイレ管理 がポイントとなる。トイレの共有を避けるのが肝要であ る. 個室管理は施設スタッフにとっては管理しやすい が，発症者にとってストレスにならないよう配慮が必要 である，食事を個室管理で行う必要はなく，食事の席で 対面とならないよう背向かいに座るなど配置し，嘔吐に 
よる感染のリスクを減らすとよい，施設職員について は，症状がなければ就業を制限する必要はないと考え る. 冬期に嘔吐があった場合, その場にいた人について は暴露を受けたと考え, 暴露後 1 日おいて発症すると予 測して事前に対応を考えておくとよい.

食品関係者における対応：ノロウイルスによる食品污 染は前出のように調理従事者によることがしばしば原因 とされ, 調理従事者の便からノロウイルスが検出される ことが多い．調理関係者の健康管理が重要であることは 周知のことであるが，ノロウイルスの問題点は不顕性感 染あるいは回復後のウイルス陽性期間内に現場復帰する ことにある ${ }^{7,24,52)}$. 現在, 不顕性感染のリスクは明らか になっていない。国内の調査では食中毒発生に関与のな い調理従事者便を検査し, 20/159 (12.3\%)がノロウイル ス陽性であった ${ }^{51)}$ 。われわれも独自に自覚症状の有無, 家族の健康状態，ノロウイルス検査を定期的に実施し, 不顕性感染の実態調査を実施中である。現在，不顕性感 染のリスクは明らかになっていないが，調理従事者にお けるノロウイルス対策として同居家族における健康状態 の把握は重要かもしれない。家族に嘔吐, 下痢症状が あった場合は，ノロウイルス感染のリスクがあるため, 無症状でも便のウイルス検査を実施するのがのぞまし い. ノロウイルスの潜伏期を考虑すると，家族発症の翌 日以降に発症あるいはウイルスを排泄することが考えら れるため，検体採取時期を考慮しなければならない。定 期検査の実施が調理施設におけるノロウイルス食中毒防 止に与える効果については十分なエビデンスが蓄積され ていない。

感染者の現場復帰については, 一般的に遺伝子検査法 でノロウイルス陰転化をもって認められている，遺伝子 検査でノロウイルスゲノムが何コピー以下になればヒト に感染・発症を引き起こさないかは明確ではない.ウイ ルスのクリアランスに関する詳細な解析ができれば，職 場復帰の新たな指標が提示できると考えられる.

迅速診断：イムノクロマト (IC) 法によるノロウイルス 感染の迅速診断は 3 歳未満および 65 歳以上にのみ保険適 用であり，診断以外に用いてはならない，対象以外の年 齢では混合診療となるため，検査を受けられない。ま た，職場復㷌のために使用することは，診断薬としての キット本来の使用目的から外れる。国内でノロウイルス 感染の迅速診断キットを製造販売しているのは 5 社であ る。しかし，遺伝子型によってキット間で検査感度の差 が認められる，GII.17に対する検査感度は臨床検体を用 いて十分に評価されているとは言えない.しかし，発症 期でウイルス排泄量が非常に高い場合は検出が可能であ る $^{63)}$.

\section{6. 最 後 に}

ノロウイルスによる急性胃腸炎は大きな社会問題と なっている。ワクチンだけでなく抗ウイルス薬の開発も
進んでいる一方, 基礎的な研究のいっそうの発展が求め られる。 ノロウイルスの感染制御対策は経験に基づいて 手探りで進められてきたが, 科学的な根拠がそしいこと も否定できない，われわれは長期にわたる疫学調査によ りノロウイルスの流行, 遺伝子型, そして免疫について 理解を深めることができた．今後もこれを継続するとと もに, 基礎的なウイルス学的研究や疫学解析によりノロ ウイルスの病原性, 宿主免疫, 生活環, 不顕性感染の実 態などを解明し，科学的根拠に基づいた感染対策への提 言につなげられるよう研究に邁進したい。

\section{文献}

1) Ahmed, S. M., Hall, A. J., Robinson, A. E., Verhoef, L., Premkumar, P., et al.: Global prevalence of norovirus in cases of gastroenteritis: a systematic review and metaanalysis. Lancet Infect. Dis., 14, 725-730 (2014).

2) Alkan, F., Karayel, I., Catella, C., Bodnar, L., Lanave, G., et al: Identification of a Bovine Enteric Calicivirus, Kirklareli Virus, Distantly Related to Neboviruses, in Calves with Enteritis in Turkey. J. Clin. Microbiol., 53, 3614-3617 (2015).

3) Atmar, R. L., Bernstein, D. I., Harro, C. D., Al-Ibrahim, M. S., Chen, W. H., et al.: Norovirus Vaccine against Experimental Human Norwalk Virus Illness. New Engl. J. Med., 365, 2178-2187 (2011).

4) Atmar RL, Opekun AR, Gilger MA, Estes MK, Crawford SE, et al:: Determination of the 50\% human infectious dose for Norwalk virus. J. Infect. Dis., 209, 10161022 (2014).

5) Ayukekbong, J.A., Fobisong, C., Tah, F., Lindh, M., Nkuo-Akenji, T. and Bergstrom, T.: Pattern of circulation of norovirus GII strains during natural infection. J. Clin. Microbiol., 52, 4253-4259 (2014).

6) Baehner, F., Bogaerts, H. and Goodwin, R.: Vaccines against norovirus: state of the art trials in children and adults. Clinical microbiology and infection. Clin. Microbiol. Infect., 2016 Apr 26. pii: S1198-743X(16)00015-X. doi: 10.1016/j.cmi.2015.12.023. (2016)

7) Barrabeig, I., Rovira, A., Buesa, J., Bartolome, R., Pinto, R., et al.: Foodborne norovirus outbreak: the role of an asymptomatic food handler. BMC Infect. Dis., 10, 269 (2010).

8) Bartsch, S. M., Lopman, B. A., Ozawa, S., Hall, A. J. and Lee, B. Y.: Global economic burden of norovirus gastroenteritis. PloS ONE, 11, e0151219 (2016).

9) Bernard, H., Faber, M., Wilking, H., Haller, S., Hohle, M., et al: Large multistate outbreak of norovirus gastroenteritis associated with frozen strawberries, Germany, 2012. Euro. Surveill., 19, 20719 (2014).

10) Bernstein, D. I., Atmar, R. L., Lyon, G. M., Treanor, J. J., Chen, W. H., et al.: Norovirus vaccine against experimental human GII.4 virus illness: a challenge study in healthy adults. J. Infect. Dis., 211, 870-878 (2015).

11) Boon, D., Mahar, J. E., Abente, E. J., Kirkwood, C. D., Purcell, R. H., et al.: Comparative evolution of GII.3 and GII.4 norovirus over a 31-year period. J. Virol., 85, 
8656-8666 (2011.)

12) Bucardo, F., Nordgren, J., Carlsson, B., Kindberg, E., Paniagua, M., et al:: Asymptomatic norovirus infections in Nicaraguan children and its association with viral properties and histo-blood group antigens. Pediatr. Infect. Dis. J., 29, 934-939 (2010).

13) Bull, R. A., Eden, J. S., Rawlinson, W. D. and White, P. A.: Rapid evolution of pandemic noroviruses of the GII.4 lineage. PLoS Pathog., 6, el000831 (2010).

14) Bull, R. A., Tu, E. T., McIver, C. J., Rawlinson, W. D., White, P. A.: Emergence of a new norovirus genotype II.4 variant associated with global outbreaks of gastroenteritis. J. Clin Microbiol., 44, 327-333 (2006).

15) Capizzi T., Makari-Judson G., Steingart R. and Mertens W. C.: Chronic diarrhea associated with persistent norovirus excretion in patients with chronic lymphocytic leukemia: report of two cases. BMC Infectious Diseases, 11, 131 (2011).

16) Chang, K. O., Sosnovtsev, S. V., Belliot, G., King, A. D. and Green, K. Y.: Stable expression of a Norwalk virus RNA replicon in a human hepatoma cell line. Virology, 353, 463-473 (2006).

17) Chaudhry, Y., Nayak, A., Bordeleau, M. E., Tanaka, J., Pelletier, J., et al.: Caliciviruses differ in their functional requirements for eIF4F components. J. Biolog. Chemist., 281, 25315-25325 (2006).

18) Currier, R. L., Payne, D. C., Staat, M. A., Selvarangan, R., Shirley, S.H., et al.: Innate Susceptibility to Norovirus Infections Influenced by FUT2 Genotype in a United States Pediatric Population. Clin. Infect. Dis.: An Official Publication of the Infectious Diseases Society of America, 60, 1631-1638 (2015).

19) Debbink, K., Lindesmith, L. C., Donaldson, E. F. and Baric RS.: Norovirus immunity and the great escape. PLoS Pathog. 8, e1002921 (2012).

20) Debbink, K., Lindesmith, L. C., Donaldson, E. F., Costantini V, Beltramello, M., et al.: Emergence of new pandemic GII.4 Sydney norovirus strain correlates with escape from herd immunity. J. Infect. Dis., 208, 1877-1887 (2013).

21) Debbink, K., Lindesmith, L. C., Ferris, M. T., Swanstom, J., Beltramello, M., et al.: Within Host Evolution Results in Antigenically Distinct GII.4 Noroviruses. J. Virol., 88, 7244-7255 (2014).

22） Eden. J. S., Hewitt, J., Lim, K. L., Boni, M. F., Merif, J., et al.: The emergence and evolution of the novel epidemic norovirus GII.4 variant Sydney 2012. Virology, 450-451, 106-113 (2014).

23) Eden, J. S., Tanaka, M. M., Boni, M. F., Rawlinson, W. D. and White, P. A.: Recombination within the pandemic norovirus GII.4 lineage. J. Virol., 87, 6270-6282 (2013).

24) Franck, K. T., Lisby, M., Fonager, J., Schultz, A. C., Bottiger B., et al: Sources of Calicivirus contamination in foodborne outbreaks in Denmark, 2005-2011-the role of the asymptomatic food handler. J. Infect. Dis., 211, 563-570 (2015).

25) Furuya, D., Kuribayashi, K., Hosono, Y., Tsuji, N., Furuya, M., et al.: Age, viral copy number, and immuno- suppressive therapy affect the duration of norovirus RNA excretion in inpatients diagnosed with norovirus infection. Jpn. J. Infect. Dis., 64, 104-108 (2011).

26) Giammanco, G. M., De Grazia, S., Terio, V., Lanave, G., Catella, C., et al: Analysis of early strains of the norovirus pandemic variant GII.4 Sydney 2012 identifies mutations in adaptive sites of the capsid protein. Virology, 450-451, 355-358 (2014).

27) Glass, R. I., Parashar, U. D. and Estes, M. K.: Norovirus gastroenteritis. New Engl. J. Med., 361, 1776-1785 (2009).

28) Goodfellow, I.: The genome-linked protein VPg of vertebrate viruses - a multifaceted protein. Curr. Opin. Virol., 1, 355-362 (2011).

29) Hall, A. J., Wikswo, M. E., Pringle, K., Gould, L. H. and Parashar, U. D.: Vital signs: foodborne norovirus outbreaks-United States, 2009-2012. MMWR Morb. Mortal. Wkly. Rep., 63, 491-495 (2014).

30) Hutson, A. M., Atmar, R. L., Graham, D. Y. and Estes MK. Norwalk virus infection and disease is associated with ABO histo-blood group type. J. Infec. Dis., 185, 1335-1337 (2002).

31) Johnson, P. C., Mathewson, J. J., DuPont, H. L. and Greenberg, H. B.: Multiple-challenge study of host susceptibility to Norwalk gastroenteritis in US adults. J. Infect. Dis., 161, 18-21 (1990).

32) Johnes, M. K., Grau, K. R., Costantini, V., Kolawole, A. O., de Graaf, M., et al.: Human norovirus culture in B cells. Nat. Protocols, 10, 1939-1947 (2015).

33) Kapikian, A. Z., Wyatt, R. G., Dolin, R., Thornhill, T. S., Kalica, A. R. and Chanock, R. M.: Visualization by immune electron microscopy of a 27 -nm particle associated with acute infectious nonbacterial gastroenteritis. J. Virol., 10, 1075-1081 (1972).

34) Kimura, H., Nagano, K., Kimura, N., Shimizu, M., Ueno, Y., Morikane, K. and Okabe, N.: A norovirus outbreak associated with environmental contamination at a hotel. Epidemiol. Infect., 139, 317-325 (2011).

35) Kirby, A. E., Streby, A. and Moe, C. L.: Vomiting as a Symptom and Transmission Risk in Norovirus Illness: Evidence from Human Challenge Studies. PloS ONE, 11, e0143759 (2016).

36) Kolawole, A. O., Li, M., Xia, C., Fischer, A. E., Giacobbi, N. S., et al: Flexibility in surface-exposed loops in a virus capsid mediates escape from antibody neutralization. J. Virol., 88, 4543-4557 (2014).

37) Kroneman, A., Vega, E., Vennema, H., Vinje, J., White, P. A., et al.: Proposal for a unified norovirus nomenclature and genotyping. Arch. Virol., 158, 2059-2068 (2013).

38) Lindesmith, L., Moe, C., Marionneau, S., Ruvoen, N., Jiang, X., et al.: Human susceptibility and resistance to Norwalk virus infection. Nat. Med., 9, 548-553 (2003).

39) Liu, P., Escudero, B., Jaykus, L. A., Montes, J., Goulter, R. M., et al.: Laboratory evidence of norwalk virus contamination on the hands of infected individuals. Appl. Environ. Microbiol., 79, 7875-7881 (2013).

40) Lopman, B. A., Trivedi, T., Vicuna, Y., Costantini, V., Collins N., et al.: Norovirus infection and disease in an 
Ecuadorian birth cohort: Association of Certain Norovirus Genotypes with Host FUT2 Secretor Status. J. Infect. Dis., 211, 1831-1821 (2015).

41) Lowther, J. A., Gustar, N. E., Powell, A. L., Hartnell, R. E. and Lees, D. N.: Two-year systematic study to assess norovirus contamination in oysters from commercial harvesting areas in the United Kingdom. Appl. Environ. Microbiol., 78, 5812-5817 (2012).

42) Lu, J., Sun, L., Fang, L., Yang, F., Mo, Y., et al.: Gastroenteritis Outbreaks Caused by Norovirus GII.17, Guangdong Province, China, 2014-2015. Emerg. Infect. Dis., 21, 1240-1242 (2015).

43) Ma, L. P., Zhao, F., Yao, L., Li, X. G., Zhou, D. Q. and Zhang, R. L.: The presence of genogroup II norovirus in retail shellfish from seven coastal cities in China. Food and Environ. Virol., 5, 81-86, 2013.

44) Mai, H., Jin, M., Guo, X., Liu, J., Liu, N., et al.: Clinical and epidemiologic characteristics of norovirus GII.4 Sydney during winter 2012-13 in Beijing, China following its global emergence. PloS ONE, 8, e71483 (2013).

45) Mans, J., Armah, G. E., Steele, A. D. and Taylor, M. B.: Norovirus epidemiology in Africa: A Review. PloS ONE, 11, e0146280 (2016).

46) Matsushima, Y., Ishikawa, M., Shimizu, T., Komane, A., Kasuo, S., et al.: Genetic analyses of GII.17 norovirus strains in diarrheal disease outbreaks from December 2014 to March 2015 in Japan reveal a novel polymerase sequence and amino acid substitutions in the capsid region. Euro. Surveill., 20, pii21173 (2015).

47) Moore, M. D., Escudero-Abarca, B. I., Suh, S. H. and Jaykus, L. A.: Generation and characterization of nucleic acid aptamers targeting the capsid $\mathrm{P}$ domain of a human norovirus GII.4 strain. J. Biotechnol., 209, 41-49 (2015).

48) Motomura, K., Yokoyama, M., Ode, H., Nakamura, H., Mori, H., et al.: Divergent evolution of norovirus GII/4 by genome recombination from May 2006 to February 2009 in Japan. J. Virol., 84, 8085-8097 (2010).

49) Murata, T., Katsushima, N., Mizuta, K., Muraki, Y., Hongo, S. and Matsuzaki, Y.: Prolonged norovirus shedding in infants $<$ or $=6$ months of age with gastroenteritis. Pediatr. Infect. Dis. J., 26, 46-49 (2007).

50) Nazaroff, W. W.: Norovirus, gastroenteritis, and indoor environmental quality. Indoor Air, 21, 353-356 (2011).

51) Okabayashi, T., Yokota, S., Ohkoshi, Y., Ohuchi, H., Yoshida, Y., et al.: Occurrence of norovirus infections unrelated to norovirus outbreaks in an asymptomatic food handler population. J. Clin. Microbiol., 46, 19851988 (2008).

52) Ozawa, K., Oka, T., Takeda, N. and Hansman GS.: Norovirus infections in symptomatic and asymptomatic food handlers in Japan. J. Clin. Microbiol., 45, 3996-4005 (2007).

53) Park, G. W., Lee, D., Treffiletti, A., Hrsak, M., Shugart, J. and Vinje, J.: Evaluation of a new environmental sampling protocol for detection of human norovirus on inanimate surfaces. Appl. Envirn. Microbiol., 81, 59875992 (2015).
54) Parra, G. I. and Green, K. Y.: Sequential gastroenteritis episodes caused by 2 norovirus genotypes. Emerg. Infect. Dis., 20, 1016-1018 (2014).

55) Perry, J. W. and Wobus, C. E.: Endocytosis of murine norovirus 1 into murine macrophages is dependent on dynamin II and cholesterol. J. Virol., 84, 6163-6176 (2010).

56) Riordan, T., Craske, J., Roberts, J. L. and Curry, A.: Food borne infection by a Norwalk like virus (small round structured virus). J. Clin. Pathol., 37, 817-820 (1984).

57) Rockx, B. H., Vennema, H., Hoebe, C. J., Duizer, E. and Koopmans, M. P.: Association of histo-blood group antigens and susceptibility to norovirus infections. J. Infect. Dis., 191, 749-754 (2005).

58) Rouhani, S, Penataro, Y. P., Paredes, O. M., Siguas, S. M., Rengifom T. D., et al.: Norovirus infection and acquired immunity in 8 countries: Results from the MALED study. Clin. Infect. Dis., 62, 1210-1217 (2016).

59) Ryder, R. W., Singh, N., Reeves, W. C., Kapikian, A. Z., Greenberg, H. B. and Sack, R. B.: Evidence of immunity induced by naturally acquired rotavirus and Norwalk virus infection on two remote Panamanian islands. J. Infect, Dis., 151, 99-105 (1985).

60) Saito, M., Goel-Apaza, S., Espetia, S., Velasquez, D., Cabrera, L., et al:: Multiple Norovirus Infections in a Birth Cohort in a Peruvian Periurban Community. Clin. Infect. Dis., 58, 483-491 (2014).

61) Sakon, N., Yamazaki, K., Nakata, K., Kanbayashi, D., Yoda, T., et al.: Impact of genotype-specific herd immunity on the circulatory dynamism of norovirus: a 10year longitudinal study of viral acute gastroenteritis. J. Infect. Dis., 211, 879-888 (2015).

62) Sakon, N., Yamazaki, K., Yoda, T., Tsukamoto, T., Kase, $\mathrm{T}$., et al.: Norovirus storm in Osaka, Japan, last winter (2006/2007). Jpn. J. Infect. Dis., 60, 409-410 (2007).

63）左近直美, 加瀬哲男：新たなノロウイルス流行株に対す る迅速体外診断薬の評価. 医学と薬学, 72, 1895-1899 (2015).

64) Sakon, N., Kase, T., Motooka, D., Nakamura, S., Komano, J.: An infant with repeated asymptomatic norovirus infections. 第63回日本ウイルス学会, 福岡 (2015).

65) Schreiber, D. S., Blacklow, N. R. and Trier, J. S.: The mucosal lesion of the proximal small intestine in acute infectious nonbacterial gastroenteritis. New Engl. J. Med., 288, 1318-1323 (1973).

66) Seitz, S. R., Leon, J. S., Schwab, K. J., Lyon, G. M., Dowd, M., et al.: Norovirus infectivity in humans and persistence in water. Appl. Environ. Microbiol., 77, 6884-6888 (2011).

67) Siebenga, J. J., Beersma, M. F., Vennema, H., van Biezen, P., Hartwig, N. J. and Koopmans, M.: High prevalence of prolonged norovirus shedding and illness among hospitalized patients: a model for in vivo molecular evolution. J. Infect. Dis., 198, 994-1001 (2008).

68) Taube, S., Kolawole, A. O., Hohne, M., Wilkinson, J. E., Handley, S. A., et al.: A mouse model for human norovirus. mBio, 16, e00450-13 (2013). 
69) Taube, S., Perry, J. W., McGreevy, E., Yetming, K., Perkins, C., et al: Murine noroviruses bind glycolipid and glycoprotein attachment receptors in a strain-dependent manner. J. Virol., 86, 5584-5593 (2012)

70) Teunis, P. F., Moe, C. L., Liu, P., Miller, S. E., Lindesmith, L., et al: Norwalk virus: how infectious is it? J. Med. Virol., 80, 1468-1476 (2008).

71) Thorne, L. G. and Goodfellow, I. G.: Norovirus gene expression and replication. J. Gen. Virol., 95, 278-291 (2014).
72) Treanor, J. J., Atmar, R. L., Frey, S. E., Gormley, R., Chen, W. H., et al.: A novel intramuscular bivalent norovirus virus-like particle vaccine candidate-reactogenicity, safety, and immunogenicity in a phase 1 trial in healthy adults. J. Infect. Dis., 210, 1763-1771 (2014).

73) Tu, E. T., Bull, R. A., Kim, M. J., McIver, C. J., Heron, L., Rawlinson, W. D. and White, P. A.: Norovirus excretion in an aged-care setting. J. Clin. Microbiol., 46, 2119-2121 (2008). 